\title{
Cele i sposoby realizacji polityki społecznej w dobie postępu technologicznego
}

\section{Streszczenie}

Celem artykułu jest naukowa refleksja nad potrzebą uwzględnienia kwestii rozwoju nowych technologii we współczesnej polityce społecznej w Polsce. Artykuł koncentruje się na omówieniu trzech wybranych obszarów polityki społecznej, na które szczególnie intensywnie oddziałują zmiany technologiczne: polityce rynku pracy, obszarze edukacji oraz usług opiekuńczych z uwzględnieniem elementów polityki senioralnej. Publikacja inicjuje dyskusję nad aktualnymi wyzwaniami i dylematami stojącymi przed polską polityką społeczną i odwołuje się do doświadczeń pandemii związanych z intensyfikacją technologicznie zapośredniczonych form komunikacji i sposobów korzystania z usług społecznych. Argumentuje, że rozwój nowych technologii zmienia zarówno cele, jak i sposoby realizacji polityki społecznej. Czerpiąc z dorobku determinizmu technologicznego i nowego instytucjonalizmu, autorka zmierza do konkluzji, że konsekwencją zmian technologicznych powinny być adekwatne zmiany instytucjonalne i formalno-prawne zapewniające większą kompatybilność systemowych rozwiązań z codzienną praktyką życia obywateli.

Słowa kluczowe: nowe technologie, polityka społeczna, rynek pracy, edukacja, teleopieka, pandemia COVID-19

Kody klasyfikacji JEL: J08, J14, J24, O33, O38

\footnotetext{
1 Uniwersytet Łódzki, Wydział Studiów Międzynarodowych i Politologicznych, e-mail: kaja.zapedowska@uni.lodz.pl, https://orcid.org/0000-0002-4399-4928
} 


\title{
Goals and ways of implementing social policies in times of technological progress
}

\begin{abstract}
This article provides a scientific reflection on the need for considering the issue of new technologies and their development in contemporary social policy in Poland. The article focuses on three selected areas of social policy, which are most intensively influenced by the development of new technologies: labor market policies, education policies, and telecare, including some elements of senior policies. The publication initiates further discussion on the current challenges and dilemmas faced by social policymakers. It corresponds to the specific experiences of the COVID-19 pandemic related to intensified, technologically mediated forms of communication and remote forms of using social services. It argues that rapid development of new technologies changes the goals and ways of putting social policies into practice. Drawing on theoretical assumptions of technological determinism and new institutionalism, the article aims to conclude that adequate institutional and legislative changes should be the consequence of technological changes and they should lead to greater compatibility of systemic solutions with citizens' everyday practice.
\end{abstract}

Keywords: new technologies, social policy, labor market, education, telecare, COVID-19 pandemic

JEL Classification Codes: J08, J14, J24, O33, O38

W myśl teorii determinizmu technologicznego rozwój nowych technologii w sposób nieodwracalny wpływa na ludzkie zachowania oraz na sposób funkcjonowania społeczeństw (Griffin, 1991). W reakcji na rewolucję technologiczną nauka poszukuje odpowiedzi na pytanie: Czy możliwe jest symbiotyczne współistnienie życia społecznego i politycznego z dobrodziejstwami wynikającymi z cyfryzacji, digitalizacji, robotyzacji i rozwoju nowych technologii informacyjno-komunikacyjnych (ICT)? Postęp cywilizacyjny znacząco wpływa na jakość życia oraz poczucie dobrostanu jednostek, grup społecznych oraz całych pokoleń (Loe, 2010; Calvo, Peters, 2014). Współczesne badania naukowe coraz częściej eksplorują tematy związane z zastosowaniem nowych technologii w sektorze usług społecznych, w teleopiece, telemedycynie, na rynku pracy oraz w obszarze gerontechnologii. Niniejszy artykuł oferuje naukową refleksję nad potrzebą uwzględnienia rozwoju nowych technologii w polityce społecznej i opiera się na dwóch tezach. Po pierwsze autorka wychodzi z założenia, że rozwój nowych technologii zmienia zarówno cele, jak i sposoby realizacji polityki społecznej. Generuje nowe wyzwania, takie jak pogłębiające się nierówności pomiędzy krajami, regionami, grupami społecznymi wyposażonymi 
w kompetencje medialne i grupami pozbawionymi dostępu do Internetu. Otwiera nowe kanały komunikacji na linii decydenci - odbiorcy instrumentów polityki społecznej. Wyposaża instytucje, polityków społecznych, pracowników socjalnych w nowe urządzenia. Umożliwia szybsze i łatwiejsze gromadzenie danych statystycznych, skuteczniejszą ewaluację programów społecznych oraz aktywną partycypację samych adresatów polityki społecznej. Po drugie autorka argumentuje, że w sytuacjach nadzwyczajnych, takich jak wybuch pandemii COVID-19, dodatkowo kładzie się nacisk na zasadność stosowania elektronicznych form świadczenia usług społecznych i zdalnych form partycypacji społecznej, począwszy od zdalnej edukacji, na telemedycynie kończąc. Zmierza do konkluzji, że dalszy postęp technologiczny, podobnie jak zmiany klimatyczne, jest nieunikniony i państwa powinny się do niego przygotować i zaadaptować.

Artykuł koncentruje się na omówieniu trzech wybranych obszarów polityki społecznej, na które szczególnie intensywnie oddziałują zmiany technologiczne: na polityce rynku pracy, obszarze edukacji oraz usług opiekuńczych z uwzględnieniem elementów polityki senioralnej. Publikacja inicjuje dyskusję nad aktualnymi wyzwaniami i dylematami stojącymi przed polską polityką społeczną, a także odwołuje się do doświadczeń pandemii związanych z intensyfikacją technologicznie zapośredniczonych form komunikacji i sposobów korzystania z usług społecznych. Czerpiąc z dorobku nowego instytucjonalizmu, autorka zmierza do konkluzji, że konsekwencją zmian technologicznych powinny być adekwatne zmiany instytucjonalne i formalno-prawne zapewniające większą kompatybilność systemowych rozwiązań z codzienną praktyką życia obywateli.

Postęp społeczny jest jednym z celów polityki społecznej. Wśród szczegółowych kryteriów postępu społecznego sformułowanych przez Daneckiego wymienić można m.in.: a) stopień przeciwdziałania dyskryminacji, b) zakres możliwości uczestniczenia jednostki w decyzjach publicznych, c) bezpieczeństwo wobec sił przyrody, d) stopień zabezpieczenia warunków dostatniego bytowania oraz e) możliwość rozwoju i pożytkowania potencjału jednostek i całego społeczeństwa (cyt. za Theiss, 2006: 14). Mimo że rozwój technologiczny nie jest wymieniony tu bezpośrednio jako determinanta lub przejaw postępu społecznego, jego udział w realizacji wszystkich wyżej wymienionych kryteriów jest kluczowy. Nowoczesne technologie: a) pomagają przeciwdziałać różnym postaciom dyskryminacji (rozszerzają dostęp do informacji, umożliwiają zdalne wykonywanie pracy grupom społecznym wykluczonym $\mathrm{z}$ tradycyjnych form świadczenia pracy, umożliwiają zdalne nauczanie w rozumieniu zarówno edukacji szkolnej, jak i poszerzania kompetencji zawodowych poprzez kursy online), b) rozszerzają zakres partycypacji jednostki w decyzjach publicznych (poprzez przejawy elektronicznej demokracji, takie jak głosowanie przez Internet, 
udział w planowaniu budżetu obywatelskiego), c) pomagają kontrolować siły przyrody (algorytmy komputerowe tworzą prognozy meteorologiczne, dzięki rozwojowi usług telekomunikacyjnych działa system alertów Rządowego Centrum Bezpieczeństwa), d) wpływają na warunki ludzkiego bytowania (ułatwiają samodzielne prowadzenie gospodarstw domowych osobom starszym i/lub niesamodzielnym, zapewniają zdalne czuwanie nad bezpieczeństwem osób dotkniętych demencją, chorobą Alzheimera, narażonych na urazy i upadki). Wynika z tego, że postęp technologiczny jest nieodłącznym elementem postępu społecznego rozumianego jako jeden z priorytetów współczesnej polityki społecznej.

Inspiracją do naukowej eksploracji tematu jest brak aktualnych krajowych opracowań i strategii poświęconych kwestii zaadaptowania nowych technologii w polityce społecznej. Od strony metodologicznej artykuł opiera się na analizie polityki publicznej (policy analysis) oraz założeniach teoretycznych nowego instytucjonalizmu i determinizmu technologicznego, prowadząc do rekonstrukcji priorytetów, zadań i celów polskiej polityki społecznej. Artykuł wieńczy propozycja transformacji w kierunku modelu „polityki społecznej 4.0., czyli otwartej na potencjał oferowany przez nowe technologie oraz wpisującej się we współczesny kierunek czwartej rewolucji przemysłowej. Artykuł ma charakter eksploracyjny i przeglądowy, a przyjęta perspektywa badawcza inicjuje i wzbogaca aktualną dyskusję nad kondycją polityki społecznej w Polsce o wątek stricte technologiczny. Na podstawie przeprowadzonej analizy zwrócono uwagę na niewystarczające uwzględnianie zmian technologicznych w perspektywicznym i strategicznym planowaniu priorytetów, celów i zadań polskiej polityki społecznej.

\section{Nowe technologie a rynek pracy}

W 2015 r. prezes Światowego Forum Ekonomicznego Klaus Schwab sformułował pojęcie „czwartej rewolucji przemysłowej”. To „uogólniająca koncepcja odnosząca się do pojęcia rewolucji, jaka ma miejsce w działalności przemysłowej w związku ze współcześnie obserwowanym systemowym wykorzystaniem technologii informacyjnych poprzez rozwój automatyzacji, przetwarzania i wymiany danych, technik wytwarzania oraz organizacji zarządzania wszystkimi procesami” (Furmanek, 2018: 56-57). Trwająca obecnie rewolucja technologiczna w sposób bezpośredni wpływa na organizację pracy i produkcji, a przez to pośrednio na warunki pracy i zatrudnienia. Zmiany te powodują długofalową, strukturalną transformację rynku pracy, co w połączeniu ze zmianami demograficznymi wskazuje nie tylko na potrzebę głębokiej restrukturyzacji, lecz także gruntownych przewartościowań po stronie zarówno 
pracodawców, jak i decydentów politycznych. „Społeczeństwo globalne staje się społeczeństwem cyfrowym, gdzie technologie jako innowacje społeczne zmieniają styl pracy, formy edukowania się i rozwoju, przynależności do sieci społecznych czy wzorce konsumpcyjne" (Grewiński, 2018: 19). Dzięki procesom automatyzacyjnym „ubywa pracy”, to znaczy, że maszyny, komputery i technologie zastępują manualne zadania wykonywane dotychczas przez człowieka. Automatyzacja fabryk i modernizacja linii produkcyjnych - procesy typowe dla drugiej połowy XX wieku - istotnie ograniczają popyt na siłę roboczą. Obecnie proces ten postępuje, ponieważ maszyny zastępują nie tylko manualny potencjał człowieka, lecz poprzez inteligentne algorytmy i komputerowe programowanie możliwe jest już oddanie kontroli nad procesami wytwórczymi inteligentnym technologiom. Do pewnego stopnia technologie mają zatem możliwość zastępowania potencjału intelektualnego człowieka. Innym wyzwaniem stojącym przed polityką rynku pracy jest digitalizacja produkcji i idea Przemysłu 4.0. Digitalizacja procesów produkcyjnych, optymalizacja procesów oraz de facto technologiczne zapośredniczenie całego łańcucha produkcyjnego - od złożenia zamówienia do dostawy do odbiorcy - istotnie redukuje zapotrzebowanie na siłę roboczą. W kontekście zastępowalności potencjału intelektualnego człowieka ciekawe jest zjawisko tak zwanego uczenia maszynowego, które „wykorzystuje automatykę do rozpoznawania i uczenia się współzależności, szczególnie w zakresie analityki predykcyjnej i normatywnej. (...) Pozwala aplikacji komputerowej na podstawie samodzielnej analizy na przewidzenie rezultatu lub podjęcie decyzji” (Kaczmarek, 2017). Do namacalnych przykładów zastępowania człowieka technologią należy m.in. obserwowany w ostatnich latach trend wdrażania kas samoobsługowych w sklepach i marketach, zastępowania interakcji w obszarze obsługi klienta inteligentnymi i dobrze skonfigurowanymi „botami” (szczególnie w sprzedaży wysyłkowej), zastępowanie siedzib placówek (na przykład banków) infoliniami i mobilnymi aplikacjami, a także wykorzystywanie potencjału drukarek 3D w obszarach wcześniej zarezerwowanych przez rzemiosło i rękodzieło (rzeźba, produkcja tkanin, chałupnictwo artystyczne i tym podobne). Wskutek automatyzacji produkcji mówi się także o zjawisku „ginących zawodów", takich jak introligatorstwo, bednarstwo, garncarstwo, kaletnictwo, grawerstwo czy szewstwo. Wyzwaniem wciąż jeszcze należącym do wizji przyszłości, lecz już technologicznie osiągalnym, jest zjawisko pojazdów autonomicznych (autonomous vehicles), które poprzez popularyzację lądowych pojazdów bezzałogowych może zrewolucjonizować procesy dystrybucyjno-dostawcze.

Postępująca cyfryzacja jest jednym z wyznaczników wzrostu konkurencyjności gospodarek, a postępu technologicznego w obszarze rynku pracy nie należy oceniać jednowymiarowo i negatywnie jako przykładu katalizatora bezrobocia. Po pierwsze nowe technologie, maszyny $\mathrm{i}$ ich oprogramowanie są nadal projektowane i wytwarzane 
przez człowieka. Sektory IT, ICT, telekomunikacji czy telemedycyny to dynamicznie rozwijające się obszary rynku pracy. Po drugie istnieją obszary z założenia niezastępowalne, takie jak praca artystyczna i kreatywna, myślenie abstrakcyjne, praca oparta na bezpośrednim i pośrednim kontakcie międzyludzkim (usługi opiekuńcze, fizjoterapia, edukacja przedszkolna). Po trzecie dzięki rozwojowi nowych technologii wiele zawodów tradycyjnie bazujących na potencjale manualnym, intelektualnym i emocjonalnym człowieka (na przykład zawód pracownika socjalnego) zyskuje ułatwienia i nowe możliwości, dzięki którym zachodzi zjawisko pewnego rodzaju fuzji potencjału ludzkiego i potencjału technologicznego. Wyposażenie pracowników w smartfony, laptopy prowadzi do ułatwienia wykonywania obowiązków, ograniczenia biurokracji, redukcji nakładu czasu pracy, skupienia na odbiorcy usług i wzrostu satysfakcji z wykonywanej pracy (Hjalmarsson, 2009).

Rozwój nowych technologii doprowadził do popularyzacji nowego modelu zatrudnienia typu „praca zdalna” wykonywana z domu. Ta forma aktywności ekonomicznej wpisuje się w jeden z priorytetów polityki społecznej Unii Europejskiej, jakim jest promowanie elastycznego modelu zatrudnienia flexicurity. Polityka zatrudnienia typu flexicurity stała się jedną z form przeciwdziałania negatywnym konsekwencjom kryzysu ekonomicznego po 2008 r., a jej nazwa wywodzi się od połączenia angielskich słów flexibility - elastyczność i security - ubezpieczenie społeczne. Unijny elastyczny model zatrudnienia, którego założenia powstały na wiele lat przed pandemią COVID-19 i niezwiązane są z ideą dystansu społecznego, adresowany jest przede wszystkim do tych grup społecznych, których pozycja na rynku pracy jest nieuprzywilejowana - do osób niepełnosprawnych, w wieku okołoemerytalnym, powracających na rynek pracy z urlopów macierzyńskich/rodzicielskich/wychowawczych. Współczesny model pracy zdalnej opiera się na technologiach informacyjno-komunikacyjnych, takich jak komputer z dostępem do Internetu i poczty elektronicznej, telefonia komórkowa, możliwość uczestniczenia w telekonferencjach z przekazem audio i wideo. Praca zdalna wykonywana w miejscu zamieszkania jest możliwa przede wszystkim w takich obszarach jak telemarketing, telebankowość, informatyka, tworzenie treści internetowych, zdalne nauczanie typu e-learning, obsługa sprzedaży wysyłkowej oraz wielu innych. W ostatnich latach w Europie zaobserwować można wzrost częstotliwości pracy zdalnej wykonywanej z domu. Według danych z 2019 r. praca zdalna była najpopularniejsza w Holandii i Finlandii - w obu krajach pracę $\mathrm{z}$ domu deklarowało $14,1 \%$ zatrudnionych między 15 . a 64. rokiem życia, podczas gdy w Polsce niecałe 5\% zatrudnionych (Eurostat, 2020). Epidemia COVID-19 spowodowała znaczny wzrost odsetka osób pracujących zdalnie z domu, a trend objął całe grupy zawodowe - nauczycieli szkolnych i akademickich, lekarzy, pracowników sektora usług. Badanie przeprowadzone w Polsce w kwietniu 2020 r., w czasie 
trwania pandemii, wykazało, że pracę zdalną z domu umożliwiło swoim pracownikom ponad 60\% dużych przedsiębiorstw (zatrudniających powyżej 250 osób) oraz ponad jedna trzecia mikroprzedsiębiorstw (zatrudniających poniżej dziewięciu osób) (Statista, 2020). Na poziomie Unii Europejskiej podobne badanie przeprowadziła Europejska Fundacja na rzecz Poprawy Warunków Życia i Pracy (Eurofound). Badanie z kwietnia 2020 r. wykazało, że w Polsce ponad 30\% ludzi zatrudnionych przeszło na model pracy zdalnej. W krajach takich jak Finlandia, Luksemburg, Holandia czy Belgia odsetek ten przekroczył 50\%, a średnia dla 27 krajów członkowskich Unii Europejskiej (po brexicie) to 37\% pracowników pracujących zdalnie (Eurofound, 2020). Tendencja ta, wskutek obniżenia kosztów leżących po stronie pracodawcy, $\mathrm{w}$ dalszej perspektywie może doprowadzić do trwałej popularyzacji modelu pracy zdalnej w realiach popandemicznych.

W kontekście strategicznego planowania celów polityki społecznej w obszarze zaadaptowania rynków pracy do postępu technologicznego na pierwszy plan wysuwa się kwestia reformy edukacji i przygotowania młodych ludzi do tzw. zawodów przyszłości. Tradycyjny model kształcenia w zinstytucjonalizowanym, kulturowo zakorzenionym cyklu życia zakłada uczestniczenie w procesie edukacji w wieku młodzieńczym, a następnie przejście do drugiego etapu życia związanego z wieloletnią produktywnością i aktywnością ekonomiczną jednostki. Tradycyjne podejście dezaktualizuje się na rzecz modelu kształcenia ustawicznego (lifelong learning), który umożliwia aktywne podnoszenie kwalifikacji na rynku pracy przez cały okres aktywności zawodowej. Kształcenie ustawiczne oraz inwestycje w kapitał ludzki są niezbędne, by podążać za rozwojem technologicznym, który w ostatnich dekadach postępuje w tempie niespotykanym w historii ludzkości. Dostosowanie instytucji odpowiedzialnych za kształcenie do modelu lifelong learning jest priorytetem również z punktu widzenia polityki społecznej wobec osób starszych. Reforma edukacji, poza uelastycznieniem systemu i umożliwieniem zdobywania wiedzy na różnych etapach życia, powinna dodatkowo zmierzać do przewartościowania zakresu wiedzy i umiejętności, w jakie wyposaża swoich uczestników. Azjatyckie analizy wpływu nowych technologii na rynek pracy bardzo silnie podkreślają pożądany kierunek transformacji od gospodarki opartej na wiedzy (knowledge-based economy) do gospodarki opartej na umiejętnościach (skills-based economy) (Institute of Systems Science, 2018), czyli zmniejszenie ilości przyswajanej wiedzy teoretycznej na rzecz uczenia się przez doświadczenie (experiential learning) oraz dalszą popularyzację modelu nauczania STEM (science, technology, engineering, mathematics) kształcącego w obszarze nauk przyrodniczo-techniczno-matematycznych.

Poza lepszym przygotowaniem kompetencyjnym pracowników do pozostałych priorytetów polityki społecznej w zakresie polityki zatrudnienia i polityki rynku 
pracy należą takie cele jak: a) zwiększanie kompetencji cyfrowych zarówno osób zatrudnionych (szkolenia zawodowe), bezrobotnych (kursy z obsługi komputera), jak i potencjalnie chętnych do aktywizacji zawodowej (np. kursy z obsługi smartfona dla seniorów i osób w wieku okołoemerytalnym), b) otwarcie rynku pracy na imigrantów, c) inwestycje w kapitał ludzki dostosowane do rzeczywistego popytu na wybrane profesje, d) podstawy programowe nauczania w szkołach podstawowych i ponadpodstawowych uwzględniające technologię informacyjną oraz naukę programowania, e) partycypacyjny model projektowania nowych technologii, uwaga skierowana na „końcowego użytkownika”, f) inkluzja kobiet, seniorów i innych niedoreprezentowanych grup społecznych do branży IT i ICT. Rewolucja technologiczna na rynku pracy w sposób bezpośredni oddziałuje na cele i priorytety systemu edukacji, którego zadaniem jest wyposażenie w wiedzę i kompetencje przyszłych pracowników.

\section{Nowe technologie w systemie edukacji}

Rozwój technologiczny i związany z nim deficyt umiejętności to jedno z najważniejszych wyzwań stojących przed krajowymi systemami edukacji, zidentyfikowanych przez Komisję Europejską. Polityka edukacyjna stymulowana jest przez europejską współpracę w dziedzinie kształcenia i szkolenia (w ramach programu Kształcenie i Szkolenie 2020), która pomaga wyznaczać priorytety wewnętrznej polityki oświatowej państw członkowskich Unii Europejskiej. Jednym z wiodących priorytetów jest rozwijanie wśród uczniów kluczowych kompetencji sprzyjających uczeniu się przez całe życie (Komisja Europejska, 2020). Projekt kształcenia ustawicznego rezonuje z priorytetami współczesnej polityki zatrudnienia i rynku pracy. Zwraca się jednocześnie uwagę na konieczność adaptacji do dynamicznie zmieniających się warunków pracy i pożądanych kompetencji związanych z postępem technologicznym. Polskie Ministerstwo Edukacji w latach 2017-2019 skupiło się na przeprowadzeniu systemowej reformy edukacji polegającej na likwidacji gimnazjów i powrocie do modelu ośmioklasowej szkoły podstawowej. W reformie zmodyfikowano co prawda podstawy programowe, zabrakło jednak refleksji nad wciąż stricte teoretycznym modelem nauczania, który wyposaża w wiedzę podręcznikową, lecz nie wykształca praktycznych umiejętności ułatwiających absolwentom odnalezienie się na rynku pracy. Ministerstwo Edukacji deklaruje wprawdzie promowanie szkolnictwa branżowego (kształcenia zawodowego), jednak nawiązywana przez Ministerstwo współpraca toruje absolwentom drogę ku tradycyjnym i nieco przestarzałym branżom (kolejnictwo, budownictwo, transport drogowy), niezwiązanym z potencjałem IT czy ICT. 
$\mathrm{W}$ atmosferze kontrowersji związanych $\mathrm{z}$ reformą systemu edukacji w Polsce wyniknęła konieczność nagłego dostosowania szkolnictwa do warunków zdalnego nauczania w związku z wybuchem epidemii COVID-19 wiosną 2020 r. Aktualnie są już dostępne pierwsze analizy i badania dotyczące jakości zdalnego nauczania w drugim semestrze roku szkolnego 2019/2020. Wnioski z badań są wartościową wskazówką dla twórców polityki społecznej zarówno w obszarze polityki edukacyjnej, jak i polityki cyfryzacji. Wyniki badań (Ptaszek et al., 2020) przeprowadzonych na próbie $\mathrm{N}=1284$ uczniów, $\mathrm{N}=979$ rodziców uczniów i $\mathrm{N}=671$ nauczycieli wskazują m.in. na znaczne obniżenie dobrostanu i samopoczucia psychicznego we wszystkich trzech badanych grupach respondentów. Dużo gorsze samopoczucie psychiczne w porównaniu z okresem przed pandemią zadeklarowało 17,8\% uczniów i uczennic, 30,1\% nauczycieli oraz 13,8\% rodziców (Ptaszek et al., 2020). Zdiagnozowano również znaczne wydłużenie czasu użytkowania cyfrowych narzędzi ekranowych w czasie doby - do ponad 6 godz. dziennie zarówno w dni powszednie, jak i w weekendy. Ponad 6 godz. dziennie spędzanych w Internecie w dni powszednie deklaruje 51\% nauczycieli oraz 49,5\% uczniów; w weekendy - 29,5\% nauczycieli oraz 28,4\% uczniów (Ptaszek et al., 2020). Powszechnym problemem sygnalizowanym zarówno przez uczniów, jak i nauczycieli jest trudność oddzielenia czasu pracy od czasu wolnego. Ze stwierdzeniem „pozostawałem/am w ciągłej gotowości do odbierania połączeń i powiadomień" zgodziło się 86,8\% nauczycieli, 65\% rodziców oraz 63,2\% uczniów (Ptaszek et al., 2020). Badania zwracają również uwagę na przewagę biernych metod nauczania typu podającego nad metodami aktywizującymi oraz niski stopień przygotowania nauczycieli do nowej formuły pracy zdalnej zarówno $\mathrm{w}$ wymiarze technicznym, jak i kompetencyjnym. Zaledwie 10,1\% nauczycieli twierdzi, że czują się w pełni przygotowani do zdalnej formy nauczania (Ptaszek et al., 2020). Skutkiem ubocznym zdalnej edukacji jest też obciążenie finansowe zarówno rodziców, jak i nauczycieli, wynikające z konieczności doinwestowania posiadanej infrastruktury technologicznej (zakup większego transferu danych, dodatkowego sprzętu i oprogramowania) (Ptaszek et al., 2020). Raport Instytutu Spraw Publicznych przeprowadzony w kwietniu 2020 r. na próbie $\mathrm{N}=646$ dyrektorów szkół podstawowych i ponadpodstawowych wskazuje $\mathrm{z}$ kolei na inne wyzwania utrudniające proces edukacji zdalnej: 88\% dyrektorów szkół podstawowych identyfikuje problem związany z koniecznością współdzielenia sprzętu potrzebnego do zdalnego nauczania, 83\% dyrektorów szkół obu typów w gminach wiejskich skarży się na ograniczenia związane z przepustowością sieci (Sobiesiak-Penszko, Pazderski, 2020). Dyrektorzy wskazują także na istotne ograniczenia w efektywności zdalnej edukacji na poziomie wczesnoszkolnym, które wynikają z konieczności asystowania młodszym dzieciom przed ekranem osoby dorosłej, dekoncentracji uwagi, trudności w aktywizacji 
uczniów online, wstydu przed występowaniem przed kamerą oraz innych czynników (Serwis Gov.pl, 2020).

Ministerstwo Edukacji w ramach wsparcia zdalnego nauczania opublikowało na swojej stronie internetowej wiele poradników skierowanych do dyrektorów szkół, nauczycieli oraz rodziców. Z punktu widzenia polityki społecznej istotnym wyzwaniem jest zjawisko cyfrowego wykluczenia, czyli problem braku dostępu do nowych technologii i oprogramowania umożliwiającego uczestniczenie w zdalnej edukacji oraz problem braku kompetencji cyfrowych niezbędnych do efektywnego użytkowania posiadanego sprzętu i oprogramowania. Ministerialny poradnik dla dyrektorów zwraca uwagę na fakt, że „żadne dziecko nie powinno znaleźć się poza systemem” (Serwis Gov.pl, 2020) oraz, że pozostawanie poza dostępem do sieci wymaga podjęcia prób nawiązania komunikacji z opiekunami dziecka metodami tradycyjnymi, takimi jak korespondencja listowna zawierająca materiały edukacyjne, kontakt telefoniczny lub przekazywanie informacji przez SMS-y (Serwis Gov.pl, 2020). W kontekście przeciwdziałania cyfrowemu wykluczeniu skuteczniejszą strategią wydaje się mimo wszystko inwestowanie $\mathrm{w}$ infrastrukturę telekomunikacyjną i informatyczną terenów niedoinwestowanych zamiast podejmowania prób uskutecznienia tradycyjnych form komunikacji. Za dobrą praktykę w tej dziedzinie może posłużyć finansowany z funduszy europejskich Program Operacyjny Polska Cyfrowa, w ramach którego od kwietnia 2020 r. przekazano $186 \mathrm{mln}$ PLN na walkę z wykluczeniem cyfrowym uczniów. Z drugiej jednak strony, w ramach rekonstrukcji rządu jesienią 2020 r. zlikwidowano w Polsce Ministerstwo Cyfryzacji, a obowiązki związane z informatyzacją zostały włączone do kompetencji Kancelarii Prezesa Rady Ministrów. W dobie wyzwań związanych z postępem technologicznym decyzja ta wydaje się perspektywicznie niezrozumiała.

Przejawem zmian w obszarze edukacji niezwiązanym bezpośrednio z kontekstem pandemii, lecz zainicjowanym postępem technologicznym, jest rozwój branży edtech (educational technology). Kilka ostatnich lat zaowocowało rozwojem elektronicznych narzędzi dydaktycznych oraz internetowych społeczności edukacyjnych. Polski lider sektora edtech - platforma Brainly oferująca rówieśniczą pomoc przy odrabianiu prac domowych - ma ponad 200 mln użytkowników na całym świecie. Masowym zainteresowaniem cieszą się również platformy do nauki języków obcych oraz multitematyczne szkoleniowe bazy danych dla nauczycieli i uczniów. Przykładem dobrej praktyki w zakresie systemowego wspierania technologii edukacyjnych w Polsce jest projekt grantowy Centrum Mistrzostwa Informatycznego na lata 2018-2023, realizowany przez pięć wiodących uczelni technicznych w kraju. Projekt jest dofinansowany ze środków Unii Europejskiej w ramach Programu Operacyjnego „Polska Cyfrowa”. Celem projektu jest „podniesienie kompetencji kadry dydaktycznej, 
tj. osób prowadzących zajęcia pozalekcyjne rozwijające zainteresowania informatyczne, a także aktywizacja młodzieży uzdolnionej informatycznie, pobudzanie kreatywności oraz promowanie współpracy zespołowej w ramach kół informatycznych" (CMI, 2018). W praktyce $w$ ramach projektu oferowane są bezpłatne szkolenia $\mathrm{z}$ zakresu algorytmiki i programowania, webinaria i granty dla uzdolnionych informatycznie uczniów. Biorąc pod uwagę zmianę pokoleniową i naturalne poruszanie się w środowisku cyfrowym przez współczesne dzieci i młodzież, można domniemywać, że sektor edtech jest przyszłościową gałęzią gospodarki, a start-upy edukacyjne mogą się stać alternatywą dla tradycyjnych podręczników.

W perspektywie długofalowej, mając na uwadze konieczność dostosowania polityki edukacyjnej do postępu technologicznego, najistotniejszym priorytetem wydaje się być transformacja modelu edukacji opartego na wiedzy (knowledge-based) w model edukacji oparty na umiejętnościach (skills based), który jest mniej zorientowany na przyswajanie wiedzy teoretycznej, a bardziej na wykształcanie praktycznych zdolności przydatnych na rynku pracy, odporniejszych na upływ czasu i technologiczną dezaktualizację. W kontekście dostosowywania modelu edukacji do zawodów przyszłości znaczenia nabiera popularyzacja modelu nauczania typu STEM (science, technology, engineering, mathematics) w obszarze nauki, technologii, inżynierii i matematyki. Doświadczenia zdalnych form nauczania z okresu trwania pandemii mogą posłużyć jako drogowskaz do potencjalnego dalszego podnoszenia jakości elektronicznej edukacji, zwłaszcza jeśli weźmie się pod uwagę jej inkluzywny potencjał względem uczniów niepełnosprawnych i pozostających na marginesie tradycyjnego systemu szkolnictwa. Elektroniczne formy kształcenia, mimo oczywistych minusów, są najskuteczniejszą możliwą drogą komunikacji w warunkach nadzwyczajnych, takich jak epidemia - głównie ze względu na szybkość i audiowizualne złudzenie bezpośredniości. Zdalne nauczanie w okresie sprzed ery Internetu prawdopodobnie przyjęłoby formę pakietów lekcji rozsyłanych korespondencyjnie, co pozbawiłoby nauczycieli możliwości integracji oraz kontroli nad stopniem uczestniczenia i zaangażowania uczniów. Warto również czuwać nad tym, by infrastrukturalne wsparcie dla szkół, które zostało udzielone w początkowym stadium pandemii, nie miało charakteru incydentalnego, lecz formę stałego finansowego strumienia wsparcia, szczególnie zważywszy na konieczność regularnych aktualizacji aplikacji, oprogramowania i wymogów sprzętowych niezbędnych do skutecznej komunikacji. 


\section{Nowe technologie w sektorze usług opiekuńczych}

W ostatnich latach w debacie publicznej pojawiły się głosy zwiastujące kryzys opieki - po pierwsze wskutek zmian demograficznych, a po drugie wskutek przemian społeczno-ekonomicznych związanych z nowym podziałem ról pomiędzy kobietami i mężczyznami (Zachorowska-Mazurkiewicz, 2010; Fraser, 2016; Graff, Ostolski, 2019). Jak zauważa Zachorowska-Mazurkiewicz, „większość modeli ekonomicznych pomija aktywność opiekuńczą, co w konsekwencji prowadzi do nieobecności tej sfery w wytycznych polityki gospodarczej. W rezultacie opieka jest niedowartościowana - wartość nieodpłatnej opieki pomijana jest w rachunkach narodowych, pracownicy opieki są nisko wynagradzani, a ich zawód nie jest prestiżowy, zaś osoby świadczące usługi opieki na rzecz członków własnego gospodarstwa domowego traktowane są jako niepracujące (bierne zawodowo). Te zjawiska przekładają się z kolei na kryzys opieki” (2010: 295). O kryzysie opieki mówi się również w kontekście rosnącego popytu na usługi medyczne i usługi opiekuńcze wynikającego ze starzenia się populacji, a w szczególności aktualnego starzenia się pokolenia powojennego wyżu demograficznego. Zmiany demograficzne - choć powinny - niekoniecznie pociągają za sobą wzrost nakładów z budżetu państwa na system ochrony zdrowia i system opieki długoterminowej. Przeciążenie systemu negatywnie odbija się na jakości usług i generuje nierówności w dostępie do nich. W nowych technologiach upatruje się potencjału usprawniającego i ułatwiającego sprawowanie opieki nad osobami starszymi i/lub niesamodzielnymi. Nowe technologie mogą pełnić funkcję komplementarną względem tradycyjnego systemu opieki i systemu ochrony zdrowia, co do pewnego stopnia zostało zrealizowane w okresie zaostrzenia pandemii poprzez przejście na zdalne świadczenie teleporad lekarskich.

Do powszechnie stosowanej grupy należą technologie asystujące, wspierające codzienne funkcjonowanie osób z dysfunkcjami narządów ruchu, słuchu lub wzroku. Coraz częściej zastosowanie znajdują również technologie monitorujące, w których skład wchodzą zarówno sensory biomedyczne (umożliwiają monitorowanie funkcji fizjologicznych na odległość), jak i monitory oddechu, czujniki dymu i tlenku węgla, detektory upadków, bransoletki umożliwiające błyskawiczne wezwanie pomocy jednym przyciskiem (Zapędowska-Kling, 2015). Przykładem włączenia nowych technologii do lokalnej oferty usług opiekuńczych jest projekt „Łódź - Miasto (Tele) Opieki”. Realizacja pilotażowej edycji rozpoczęła się w maju 2018 r., a zakończyła w marcu 2021 r. Projekt finansowany był z Regionalnego Programu Operacyjnego Województwa Łódzkiego w ramach osi priorytetowej „Włączenie społeczne” i poddziałania „Usługi społeczne i zdrowotne”. Grupą docelową projektu byli niesamodzielni 
seniorzy w wieku 60+, zamieszkujący miasto Łódź, którzy wcześniej nie korzystali z przywilejów teleopieki. Niesamodzielność musiała zostać stwierdzona w odniesieniu do minimum jednej czynności według skali Barthel. Jednym z dodatkowych kryteriów kwalifikujących do udziału w projekcie było zamieszkiwanie w jednoosobowym gospodarstwie domowym, czyli brak bezpośredniego towarzystwa w życiu codziennym, a co za tym idzie ograniczona możliwość niesienia pomocy w sytuacjach zagrażających zdrowiu i życiu (HRP, 2020). Analogicznym projektem jest „Małopolski Tele-Anioł", którego okres realizacji jest dłuższy i trwa od kwietnia 2018 r. do czerwca 2022 r. Grupą docelową projektu małopolskiego są osoby w wieku 75+ (bez konieczności przedstawienia oświadczenia o niesamodzielności) lub młodsze, posiadające oświadczenie o niesamodzielności. Kryterium kwalifikującym do otrzymania bransoletki jest „niemożność samodzielnego wykonywania co najmniej jednej z podstawowych czynności dnia codziennego (np. samodzielne robienie zakupów, przygotowywanie i spożywanie posiłków, sprzątanie, poruszanie się, wychodzenie z domu, ubieranie i rozbieranie, higiena osobista itp.)" (Serwis Małopolska.pl, 2018). Technologiczną podstawą obu projektów jest wyposażenie zakwalifikowanych do programu seniorów w opaski z lokalizacją GPS i przycisk alarmowy umożliwiający całodobową łączność z Centrum Opieki. W ramach projektu łódzkiego rozdano 2000 opasek, w ramach małopolskiego - 6000 opasek. Dodatkowo, program łódzki dla 40 najbardziej niesamodzielnych beneficjentów przewidział możliwość świadczenia opieki pielęgniarskiej w miejscu zamieszkania, a program małopolski 1800 beneficjentów objął usługami opiekuńczymi i sąsiedzkimi usługami opiekuńczymi. Bransoletki poza możliwością szybkiej geolokalizacji osoby podopiecznej na bieżąco monitorują tętno oraz wykrywają upadek. Niepokojącym faktem jest brak możliwości kontynuacji pierwszej edycji projektu „Łódź Miastem (Tele) Opieki”, która zakończyła się w marcu 2021 r. Według danych udostępnionych przez Oddział ds. Polityki Senioralnej Urzędu Miasta Łodzi projekt nie uzyskał środków finansowych niezbędnych do jego kontynuacji. W konsekwencji 2000 opasek zostało odebranych seniorom, a Centrum Teleopieki zostało deaktywowane. Do decyzji tej przyczynić się miały warunki pandemii generujące rosnące koszty programu. Z punktu widzenia priorytetów zawartych w strategii Polityka społeczna wobec osób starszych 2030. Bezpieczeństwo- Uczestnictwo-Solidarność decyzja jest błędna, ponieważ prowadzi do zmarnowania zaplecza infrastrukturalnego i wypracowanych procedur opiekuńczych, a co gorsza - do odebrania uczestnikom programu poczucia bezpieczeństwa i potencjalnej całodobowej asysty, niwecząc tym samym innowacyjny i postępowy charakter pierwszej edycji programu.

Wspomniany dokument Polityka społeczna wobec osób starszych 2030. Bezpieczeństwo - Uczestnictwo - Solidarność określa kierunki i priorytety polskiej polityki 
senioralnej w horyzontalnej perspektywie do 2030 r. Dokument formułuje pięć kluczowych priorytetowych celów w polityce społecznej wobec osób starszych, z których jeden brzmi: „zastosowanie nowych technologii w opiece nad osobami starszymi i kompleksowe monitorowanie ich poziomu zdrowia, np. poprzez rozwój telemedycyny i teleopieki” (Monitor Polski, 2018: 12). Dokument podkreśla również korzyści płynące z projektowania uczestniczącego usług elektronicznych („projektowanie zorientowane na użytkownika”), zwraca uwagę na konieczność zapewnienia osobom starszym dostępu do informacji i komunikacji, w tym technologii i systemów informacyjno-komunikacyjnych zarówno na obszarach miejskich, jak i wiejskich, podkreśla znaczenie użytkowania „Internetu i innych technologii teleinformatycznych do korzystania z dóbr kultury, rozrywki, edukacji oraz komunikacji z innymi osobami” (Monitor Polski, 2018: 37). Zwraca także uwagę na „możliwości zwiększenia aktywności zawodowej dzięki zastosowaniu Internetu i innych technologii telekomunikacyjnych” (2018: 40) oraz na „wykorzystanie nowoczesnych technologii dla rekompensowania utraconej sprawności i wzmacniania samodzielności” (2018: 44). Wskazuje także na „generacyjny charakter nowych technologii” (2018: 52), który - w przypadku braku adekwatnej edukacji - stanowić może barierę w komunikacji i integracji międzypokoleniowej. Z punktu widzenia założeń teoretycznych strategia wyraża nie tylko świadomość bardzo istotnego znaczenia nowych technologii dla kreowania polityki senioralnej w przyszłości, ale także wolę ich zaadaptowania w wybranych obszarach usług społecznych. Podstawową słabością tego typu polityki jest brak konkretnej strategii wykonawczej. Wiele prawidłowo sformułowanych priorytetów pozostanie w warstwie deklaratywnej.

Potencjalnym instrumentem finansowym umożliwiającym praktyczne wcielanie w życie priorytetów Polityki społecznej wobec osób starszych 2030 są programy rządowe „Opieka 75+” oraz „Aktywni+”. Program „Opieka 75+” skierowany jest do małych gmin (do 60 tys. mieszkańców), a jego celem jest „poprawa dostępności do usług opiekuńczych, w tym specjalistycznych usług opiekuńczych, dla osób w wieku 75 lat i więcej" (MRiPS, 2019). Gminy biorące udział w programie mogą liczyć na refundację do 50\% kosztów realizacji usług opiekuńczych dla seniorów. Biorąc pod uwagę obserwowany wzrost odsetka osób korzystających z usług opiekuńczych oraz specjalistycznych usług opiekuńczych (wzrost o 6\% liczby osób, którym przyznano usługi opiekuńcze w 2018 r. względem 2017 r. oraz wzrost o 19\% liczby osób, którym przyznano specjalistyczne usługi opiekuńcze w 2018 r. względem 2017 r. według Raportu Ministerstwa Rodziny, Pracy i Polityki Społecznej Program „Opieka 75+" na rok 2020), gminy biorące udział w programie „Opieka 75+” mogłyby się posiłkować telerozwiązaniami na wzór projektu małopolskiego i łódzkiego. Opaski monitorujące podstawowe parametry życiowe, wyposażone w przycisk alarmowy 
i lokalizator GPS, umożliwiają pełnienie opieki równolegle nad wieloma uczestnikami pod warunkiem, że podopieczni nie wymagają bezpośredniej asysty przy wykonywaniu podstawowych czynności dnia codziennego. Z tego punktu widzenia omawiana forma teleopieki jest rozwiązaniem relatywnie ekonomicznym, przy jednoczesnym umożliwieniu osobom starszym zamieszkiwania we własnym gospodarstwie domowym. Program „Aktywni+” z kolei nastawiony jest na włączenie cyfrowe osób starszych, a jednym z jego priorytetów są „działania na rzecz zwiększenia umiejętności posługiwania się nowoczesnymi technologiami i korzystania z nowych mediów przez osoby starsze, a także upowszechnianie i wdrażanie rozwiązań technologicznych sprzyjających włączeniu społecznemu oraz bezpiecznemu funkcjonowaniu osób starszych" (Departament Polityki Senioralnej, 2021a). Formuła programu zakłada dofinansowanie lokalnych inicjatyw realizowanych przez organizacje pozarządowe oraz inne podmioty działające na rzecz osób starszych. W latach 2021-2025 jednorazowe dofinansowanie może wynieść od 25 do 250 tys. PLN. W ramach priorytetu „Włączenie cyfrowe” w 2021 r. dofinansowanie otrzymało 81 projektów na łączną kwotę prawie $10 \mathrm{mln}$ PLN. Wśród dofinansowanych projektów dominują pomysły zorientowane na zapewnienie seniorom bezpieczeństwa w cyberprzestrzeni, doskonalące kompetencje cyfrowe oraz umożliwiające aktywizację zawodową, społeczną lub kulturalną poprzez wykorzystanie nowych technologii informacyjno-komunikacyjnych (Departament Polityki Senioralnej, 2021b).

Warto wspomnieć, że w trakcie trwania pandemii w formule online funkcjonowały lokalne Centra Seniora, których oferta przyjęła formę zajęć zdalnych. Dla przykładu, Centrum Zdrowego i Aktywnego Seniora w Łodzi prowadziło cotygodniowe zdalne zajęcia ruchowe typu „Zumba” i „Taniec w kręgu” poprzez wideopołączenia na platformie Zoom, a także cykliczny instruktaż obsługi smartfona, zajęcia z rękodzieła oraz zajęcia intelektualne typu „gimnastyka umysłu”. Warto zauważyć, że tego typu zdalne formy integracji - jakkolwiek wartościowe i podtrzymujące na duchu, posiadające walory terapeutyczne i imitujące regularne spotkania z grupą rówieśniczą - wymagają posiadania podstawowych kompetencji cyfrowych oraz spełnienia minimalnych wymogów sprzętowych. To powoduje, że nadrzędnym priorytetem w obszarze polityki senioralnej pozostaje walka z cyfrowym wykluczeniem, w dalszej kolejności uzupełniana zwiększaniem podaży kursów, zajęć i innych funkcjonalności w wersji online.

\section{$* * *$}

Postępująca, głęboka integracja nowych technologii i polityki społecznej wydaje się nieunikniona. Doświadczenia pandemii zmieniły optykę postrzegania postępu technologicznego - już nie jako „zagrożenia”, lecz „potencjału” podnoszącego jakość 
życia w warunkach lockdownu. Opisane w artykule zmiany obserwowane na rynku pracy, w sektorze edukacji oraz w sektorze usług opiekuńczych, mimo że wciąż „innowacyjne”, z biegiem czasu nabiorą charakteru systemowych przemian, które na stałe wcielą kwestie technologiczne do programów kształcenia szkolnego i ustawicznego. Doświadczenia pandemii zmusiły jednostki do samodzielnego dokształcania się w zakresie zdalnych form komunikacji i korzystania z usług społecznych - przy zaangażowaniu i pomocy członków rodziny, sąsiadów, przyjaciół. Seniorzy z dnia na dzień zostali postawieni przed koniecznością korzystania z teleporad lekarskich, telezakupów i rozmaitych form elektronicznej administracji. Z punktu widzenia aktorów polityki społecznej odpowiedzialność za jakość funkcjonowania została $\mathrm{w}$ dużej mierze przerzucona $\mathrm{z}$ sektora publicznego na jednostki, ich rodziny oraz społeczności hiperlokalne, będąc tym samym symptomem refamilizacji i zwrotu w kierunku komplementarnego potencjału trzeciego sektora. Obecnie, gdy warunki życia wracają do ładu z okresu sprzed pandemii, nadszedł czas na rozwiązania o charakterze systemowym i powszechnym. Adaptacja do rewolucji technologicznej przyjmuje formę nowo tworzonych portali i baz danych, takich jak Internetowe Konto Pacjenta, Platforma Usług Elektronicznych ZUS, elektroniczny profil podatnika Urzędu Skarbowego czy Profil Zaufany. Coraz częściej zastosowanie znajduje instytucja elektronicznego obiegu dokumentów oraz elektronicznego podpisu. Oferta komercyjna sektora prywatnego dodatkowo napędza przemiany. Nowe technologie są jednym $\mathrm{z}$ filarów srebrnej gospodarki, a opisane w tekście innowacyjne rozwiązania, takie jak geolokalizacja GPS czy urządzenia monitorujące parametry życiowe, są dostępne odpłatnie na rynku dóbr i usług. U podstaw przemian instytucjonalnych leży konieczność przewartościowania priorytetów krajowej polityki makroekonomicznej i sposobów gospodarowania budżetem państwa, który tradycyjnie nadaje pierwszeństwo celom populistycznym (na przykład realizacja programu 500+ bez jakichkolwiek kryteriów dochodowych), celom związanym z obroną narodową (na przykład modernizacja armii) lub celom nacechowanym ideologicznie (na przykład wysokie subwencje z budżetu państwa dla medialnych nadawców publicznych). Świadome zmierzanie w kierunku realizacji modelu „Polityki społecznej 4.0." (Pulkka, 2021) wymaga po pierwsze realizacji szeroko zakrojonej kampanii edukacyjno-informacyjnej, której celem byłoby podnoszenie świadomości w zakresie zarówno potencjalnych korzyści, jak i potencjalnych zagrożeń płynących z użytkowania nowych technologii informacyjno-komunikacyjnych, a po drugie współpracy władz z jednostkami samorządu terytorialnego poprzez przekierowanie strumienia dofinansowania bezpośrednio do gmin wraz z odgórną priorytetyzacją zadań ukierunkowanych na przeciwdziałanie cyfrowemu wykluczeniu oraz wdrażanie nowych technologii do sektora usług społecznych. Niebagatelne 
znaczenie ma także pełne i strategiczne wykorzystanie potencjału programów i projektów unijnych, które stanowią zewnętrzny impuls do nadganiania zagranicznych standardów w obszarach związanych z ochroną środowiska, systemem ochrony zdrowia, infrastrukturą teleinformatyczną i opieką nad osobami niesamodzielnymi. Jeżeli postęp technologiczny jest jednym z przejawów postępu społecznego, to automatycznie staje się również priorytetem polityki społecznej.

\section{Źródło finansowania}

Publikacja jest rezultatem indywidualnego grantu naukowo-badawczego pt. Zastosowanie nowych technologii w polityce społecznej finansowanego ze środków Uniwersytetu Łódzkiego w ramach programu „Inicjatywa Doskonałości - Uczelnia Badawcza" (numer umowy 30/IDUB/MLOD/2021).

\section{Bibliografia}

Calvo, R.A., Peters, D. (2014). Positive Computing: Technology for Wellbeing and Human Potential. Cambridge, MA: MIT Press.

Centrum Mistrzostwa Informatycznego (2018). Cel projektu, https://cmi.edu.pl/mod/page/ view.php?id=1 (dostęp: 1.09.2021).

Departament Polityki Senioralnej (2021a). Program wieloletni na rzecz Osób Starszych „Aktywni+” na lata 2021-2025, http://senior.gov.pl/aktualnosci/pokaz/545 (dostęp: 2.03.2021).

Departament Polityki Senioralnej (2021b). Wyniki otwartego konkursu ofert w ramach Programu Wieloletniego na rzecz Osób Starszych „Aktywni+” na lata 2021-2025, http://senior. gov.pl/program_asos/pokaz/566 (dostęp 3.06.2021)

Eurofound (2020). Living, Working and COVID-19. First findings - April 2020, https://www. eurofound.europa.eu/sites/default/files/ef_publication/field_ef_document/ef20058en.pdf (dostęp: 23.09.2020).

Eurostat (2020). How Useful It Is to Work from Home?, https://ec.europa.eu/eurostat/web/products-eurostat-news/-/DDN-20200424-1 (dostęp: 23.09.2020).

Fraser, N. (2016). Contradictions of Capital and Care, New Left Review, 100: 99-117.

Furmanek, W. (2018). Najważniejsze idee czwartej rewolucji przemysłowej (Industrie 4.0). Dydaktyka Informatyki 3: 55-63.

Gov.pl (2020). Poradnik dla dyrektorów, https://www.gov.pl/web/zdalnelekcje/poradnik-dla-dyrektorow (dostęp: 3.03.2021).

Graff, A., Ostolski, A. (2019). Gender Ideology and the Crisis of Care in Poland, Green European Journal, 17.12, https://www.greeneuropeanjournal.eu/gender-ideology-and-the-crisis-of-care-in-poland/ (dostęp: 3.06.2021). 
Grewiński, M. (2018). Cyfryzacja i innowacje społeczne - perspektywy i zagrożenia dla społeczeństwa. Kwartalnik Nauk o Przedsiębiorstwie, 1: 19-29.

Griffin, E. (1991). Technological Determinism of Marshall McLuhan. W: A First Look at Communication Theory (291-300), Emory A. Griffin (red.). New York, NY: McGraw-Hill.

Hjalmarsson, M. (2009). New Technology in Home Help Services - A Tool for Support or an Instrument of Subordination?, Gender, Work, and Organization, 16(3): 368-384.

HRP (2020). Łódź - Miasto (Tele)Opieki, https://hrp.com.pl/projekty/lmto/\#opis-projektu (dostęp: 1.06.2021).

Institute of Systems Science (2018). The Rise of a Skills-Based Economy. National University of Singapore, https://www.iss.nus.edu.sg/community/newsroom/news-detail/2018/06/25/ the-rise-of-a-skills-based-economy (dostęp: 14.01.2021).

Kaczmarek, S. (2017). Machine learning i deep learning - samouczace systemy. Leksykon 2017, http://it-filolog.pl/machine-learning-i-deep-learning-samouczace-systemy-leksykon-2017/ (dostęp: 17.03.2021).

Komisja Europejska (2020). Wsparcie UE na rzecz polityki oświatowej, https://ec.europa.eu/ education/policies/school/about-school-policy_pl (dostęp: 20.04.2021).

Loe, M. (2010). Doing It My Way: Old Women, Technology and Wellbeing. Sociology of Health and Illness 32(2): 319-334.

Małopolska.pl (2018). Małopolski Tele-Anioł, https://www.malopolska.pl/teleaniol (dostęp: 31.05.2021).

Ministerstwo Rodziny i Polityki Społecznej, (2019). Program „Opieka 75+”, https://www.gov. pl/web/rodzina/program-opieka-75 (dostęp: 3.06.2021).

Monitor Polski (2018). Uchwała nr 161 Rady Ministrów z dnia 26 października 2018 r. w sprawie przyjęcia dokumentu „Polityka społeczna wobec osób starszych 2030. Bezpieczeństwo - uczestnictwo - solidarność", https://www.monitorpolski.gov.pl/M2018000116901.pdf (dostęp: 14.02.2021).

Ptaszek, G., Bigaj, M., Dębski, M., Pyżalski, J. i Stunża, G.D. (2020). Zdalna edukacja - gdzie byliśmy, dokąd idziemy? Wstępne wyniki badania naukowego „Zdalne nauczanie a adaptacja do warunków społecznych w czasie epidemii koronawirusa”, https://ug.edu.pl/ news/sites/ug.edu.pl.news/files/2020-06/Badanie\%20zdalnenauczanie_prezentacja_1. pdf (dostęp: 12.12.2020).

Pulkka, V. (2021). Social Policy 4.0? Empirical Insights into the Future of Work and Social Policy in the Digital Economy, rozprawa doktorska, Faculty of Social Sciences, University of Helsinki, Helsinki: Unigrafia, https://helda.helsinki.fi/handle/10138/328690 (dostęp 29.08.2021).

Sobiesiak-Penszko, P., Pazderski, F. (2020). Dyrektorzy do zadań specjalnych - edukacja zdalna w czasach izolacji. Prezentacja wyników badania. Instytut Spraw Publicznych, https://www. isp.org.pl/uploads/drive/aktualnosci/RAPORT_Dyrektorzy_do_zadan_specjalnych_08.06. pdf (dostęp 20.01.2021).

Statista (2020), Share of employees working remotely during the coronavirus (COVID-19) epidemic in Poland in 2020, by company size, https://www.statista.com/statistics/1117347/polandshare-of-employees-working-remotely-during-covid-19/ (dostęp: 23.09.2020). 
Theiss, M. (2006). Jana Daneckiego (1928-2006) tezy o rozwoju społecznym. Problemy Polityki Społecznej. Studia i Dyskusje, 9: 13-19.

Zachorowska-Mazurkiewicz, A. (2010). Kryzys opieki - jego przyczyny oraz propozycje sposobów przezwyciężania. W: Jakość życia a procesy zarzadzania rozwojem i funkcjonowaniem organizacji publicznych (295-310), A. Noworól (red.). Kraków: Instytut Spraw Publicznych Uniwersytetu Jagiellońskiego.

Zapędowska-Kling, K. (2015). Nowe technologie w służbie seniorom. Acta Universitatis Lodziensis. Folia Oeconomica, 4(315): 203-215. 